\title{
Corporate Social Responsibility Policy in the United States of America
}

\author{
By Mark Anthony Camilleri ${ }^{12}$ (Ph.D. Edinburgh)
}

This is a prepublication version.

How to Cite: Camilleri, M.A. (2017). Corporate Social Responsibility Policy in the United States of America. In: Idowu S., Vertigans S., Schiopoiu Burlea A. (eds.) Corporate Social Responsibility in Times of Crisis.

CSR, Sustainability, Ethics \& Governance. Cham, Switzerland, Springer Nature. DOI https://doi.org/10.1007/978-3-319-52839-7_7

\begin{abstract}
This contribution evaluates the United States (U.S.) government's policies on corporate social responsibility (CSR) and environmentally-sustainable behaviors. It looks at the establishment of particular corporate citizenship procedures and expectations. US entities, including bureaus, agencies and non-governmental organizations (NGOs) have often interpreted their own view on business ethics and stakeholder engagement, within their own regulatory context. This conceptual paper suggests that relevant policies, guidelines and communication on corporate citizenship and their disclosures can change the companies' attitudes toward CSR, sustainability and corporate governance reporting. It has presented numerous opportunities for businesses to engage in CSR practices in order to create value for themselves and for others. In conclusion, as corporate citizenship and social responsibility policies are widely-understood, accepted and implemented by stakeholders, there will be greater convergence of laudable behaviors. This will ultimately bring positive implications for a sustainable and fair future for all.
\end{abstract}

Keywords: Corporate Citizenship, Social Responsibility, Environmental Responsibility, Sustainability, Stakeholder Engagement, CSR Policies, USA CSR Policies.

\footnotetext{
${ }^{1}$ Department of Corporate Communication, Faculty of Media and Knowledge Sciences, University of Malta, Msida, MDS2080, MALTA. Email: mark.a.camilleri@um.edu.mt

2 The Business School, University of Edinburgh, Bucchleuch Place, Edinburgh, EH8 9JS, SCOTLAND.
} 


\section{Introduction}

The US markets for labor and capital are fairly unregulated as there are low levels of welfare state provision. Consequently, many social issues, such as education, healthcare or community investment have traditionally been at the core of corporate social responsibility (CSR) in the American context. CSR initiatives and communicating activities within the areas of philanthropy, stewardship, volunteerism and environmental affairs are not treated as a regulatory compliance issue in the United States of America (USA or U.S.). Therefore, CSR in the USA is often characterized by voluntary societal engagements by businesses as they are not obliged to undertake social and environmental responsibility practices. Such laudable behaviors are also referred to as corporate citizenship (Fifka, 2013; Matten and Crane, 2005). Social Responsibility and corporate citizenship encompass responsible behaviors that go beyond financial reporting requirements. These behaviors are particularly evidenced in causerelated marketing, stewardship initiatives, philanthropic and charitable contributions (Porter and Kramer, 2002; Varadarajan and Menon, 1988). In fact, US companies donate ten times as much as their British counterparts (Brammer and Pavelin, 2005). Notwithstanding, at this point in time, the United States is currently consuming some 207 percent of its ecological capacity (Worldwatch, 2015.) and the average U.S. citizen uses 11 times as many resources as the average Chinese, and 32 times as much as the average Kenyan (Worldwatch, 2015.). Moreover, the United States was a net importer of 67 non-fuel minerals and metals out of the 92 tracked by the U.S. Geological Survey (2010). Nonetheless, the American policy makers handle the issues that are related to global warming or the use of genetically modified organisms in food production, quite differently than their counterparts (Doh and Guay, 2006). In other parts of the world, the provisions of healthcare or issues pertaining to the climate change have traditionally been considered in the realms of government's responsibilities. Corporate responsibilities for social and environmental issues seem to have become the object of codified and mandatory regulation in certain jurisdictions (Camilleri, 2015). Therefore, it may appear that the larger firms rather than small and medium sized enterprises (SMEs) are the leading actors and drivers of CSR engagement and sustainable behaviors.

This conceptual paper reports that responsible practices are increasingly being embedded into core business functions and corporate strategic decisions. In this light, it sheds light on major US institutional frameworks and principles that have been purposely developed to foster a 
climate for social and environmental responsibility engagement. Policies and voluntary instruments include formal accreditation systems and soft laws that stimulate businesses and large organizations to implement and report their CSR-related activities. Several agencies of the US Government are currently employing CSR programs that are intended to provide guidance on corporate citizenship and human rights; labor and supply chains; anticorruption; energy and the environment; as well as health and social welfare among other issues. Firstly, this chapter introduces its readers to the notion of corporate citizenship as it draws comparisons with other CSR concepts. Secondly, it makes reference to empirical studies that have explored how organizations were engaging in economic, legal, ethical and discretionary behaviours toward stakeholders. Thirdly, this contribution also reports on the American corporate citizenship policies that are intended to support major areas of responsible corporate conduct in the realms of social responsibility and environmental sustainability. The author provides an interesting discussion on how policies and principles are raising awareness of the CSR agenda in the U.S. context. Finally, this chapter implies that appropriate policy frameworks and initiatives necessitate considerable discretionary investments as they pursue the sustainable path.

\section{Corporate Citizenship}

Corporate citizenship offers ways of thinking and behaving responsibly (Matten and Crane, 2005). It has potential to unlock significant benefits to both business and society (Carroll and Shabana, 2010). Sound environmental practices could be linked to improvements in economic performance and productivity, operational efficiencies, higher quality, innovation and competitiveness (Porter and Kramer, 2011). Therefore, corporate citizenship (through social responsibility and environmental sustainability) can be strategic in its intent and purposes (Basu and Palazzo, 2008; Burke and Logsdon, 1996). An integration of these different perspectives has led to the definition of corporate citizenship. The conceptual grounds to better understand the nature of corporate citizenship can be found in the bodies of literature on corporate social responsibility (e.g., Carroll, 1979), corporate social responsiveness (e.g., Clarkson, 1995), corporate social performance (e.g., Wartick and Cochran, 1985; Wood, 1991; Albinger and Freeman, 2000), and stakeholder engagement (Strand and Freeman, 2013). Carroll (1979) attempted to synthesise the fundamental principle of social responsibility. He explained the rationale behind social responsibility initiatives and went on to describe the 
corporate responses to social issues. Businesses always had a commitment towards society as they are obliged to engage in economic, legal, ethical and discretionary (philanthropic) activities (Carroll, 1979).

For instance, CSR's economic responsibilities include the obligations for businesses to maintain economic growth, and to meet consumption needs. The economic component of CSR represents the fundamental social responsibility of businesses. Many firms produce goods and services and sell them at fair prices. This will in turn allow the business entity to make a legitimate profit and to pursue growth. Legal responsibilities imply that businesses must fulfil their economic mission within the extant framework of regulations and legal parameters. The legal component recognises the obligation of the enterprise to obey laws. However, it could prove harder to define and interpret the ethical responsibilities of businesses. This component is often referred to as a "grey area", as it "involves behaviours and activities that are not embodied in law but still entail performance expected of business by society's members" (Carroll, 1979:30). Ethical responsibilities require that businesses abide by moral rules that define appropriate behaviours within a particular society. Another category of corporate responsibility is related to discretionary, voluntary or philanthropic issues. Corporate philanthropy is a direct contribution by a corporation to a charity or cause, most often in the form of cash grants, donations and/or in-kind services' Kotler and Lee (2005: 144). This category of social responsibility is totally dictated at the "discretion" of the organisation as there are no laws or codified expectations guiding the corporations' activities (Rasche, De Bakker and Moon, 2013). "Discretionary responsibilities include those business activities that are not mandated, not required by law, and not expected of businesses in an ethical sense" (Carroll, 1979:500). Practically, some examples where organisations meet their discretionary responsibilities, include; when they provide day-care centres for working mothers, by committing to philanthropic donations, or by creating pleasant work place aesthetics. Carroll (1991) describes these four distinct categories of activity by illustrating a "Pyramid of Corporate Social Responsibility". He maintained that his conceptualisation of the pyramid depicts the obligations of the business. Eventually, Schwartz and Carroll (2003) suggested an alternative approach that is based on three core domains (economic, legal and ethical responsibilities). The authors produced a Venn diagram with three overlapping domains; which were later transformed to seven CSR categories. This development was consistent with the 
relentless call on the part of the business community for the business case of CSR. Kotler and Lee (2005) demonstrated how a CSR approach had established a new way of doing business that led to the creation of value (Wheeler, Colbert and Freeman, 2003; Porter and Kramer, 2011) with a respectful and proactive attitude towards stakeholders (Strand and Freeman, 2013).

Corporate citizenship continues to receive specific attention, particularly by those facilities that are operating outside their own domestic markets. At the same time, multinational corporations (MNCs) have been (and still are) under increasing pressure to exhibit "good corporate citizenship" in every country or market from where they run their business. MNCs have always been more closely monitored and scrutinised than the home country firms. No doubt this will continue to be the case in the foreseeable future.

\section{Measuring Corporate Citizenship}

Several empirical studies have explored the respondents' attitudes and perceptions on corporate social responsibilities. Very often, the measurement of corporate citizenship could have involved quantitative analyses on organisational commitment toward responsible organisational behaviours (Maignan, Ferrell and Hult, 1999; Aupperle, Carroll and Hatfield, 1985). Therefore, their survey responses could not have revealed and explained actual corporate citizenship practices. Other research could have focused on investigations of managerial perceptions of corporate citizenship rather than focusing on corporate behaviours (e.g., Basu and Palazzo, 2008; Singhapakdi, Kraft, Vitell and Rallapalli, 1995). A number of similar studies have gauged corporate citizenship by adopting Fortune's reputation index (Fryxell and Wang, 1994; Griffin and Mahon, 1997; Stanwick and Stanwick, 1998), the KLD index (Fombrun, 1998; Griffin and Mahon, 1997) or Van Riel and Fombrun's (2007) Reptrak. Such measures require executives to assess the extent to which their company behaves responsibly toward the environment and the community (Fryxell and Wang, 1994). Despite their wide usage in past research, the appropriateness of these indices remains doubtful. For instance, Fortune's reputation index failed to account for the multi-dimensionality of the corporate citizenship construct and is suspected to be more significant of management quality than of corporate citizenship (Waddock and Graves, 1997). Fortune's past index suffered from the fact that its items were not based on theoretical arguments as they did not appropriately 
represent the economic, legal, ethical, and discretionary dimensions of the corporate citizenship construct. Hunt, Wood and Chonko's (1989) investigated broad based perceptions on (a) the extent to which employees perceive that managers are acting ethically in their organisations (b) the extent to which employees perceive that their managers are concerned about the issues of ethics in their organisations and (c) the extent to which employees perceive that ethical (or unethical) behaviour is rewarded (or punished) in their organisation. Other authors, including Webb, Mohr and Harris (2008) also explored the philanthropic values that were related socially responsible consumption.

Pinkston and Carroll (1994) identified four dimensions of corporate citizenship, including; orientations, stakeholders, issues, and decision-making autonomy. They argued that by observing orientations, one may better understand the inclinations or posturing behaviours of organisations with respect to corporate citizenship. The stakeholder dimension should better define to whom the organisation feels responsible as it could identify where the corporate citizenship issues or social concerns are originating. The aspect of decision-making autonomy was believed to illuminate the perceived importance of corporate citizenship as one that determines at what organisational level corporate citizenship decisions are actually made. In a similar vein, Griffin and Mahon (1997) combined four estimates of corporate citizenship: the Fortune reputation index, the KLD index, the Toxic Release Inventory (TRI), and the rankings provided in the Directory of Corporate Philanthropy. They admitted that their four measures do not necessarily track one another. Such findings suggest that these indicators may not be representative of the same underlying construct and their items may not be sufficient to provide an overall understanding of corporate citizenship.

Singh, De los Salmones Sanchez and Rodriguez del Bosque (2007) adopted a multidimensional perspective on three domains, including; commercial responsibility, ethical responsibility and social responsibility. Firstly, they proposed that commercial responsibility of businesses relates to their continuous development of high quality products and truthful marketing communications of their products' attributes and features among customers. Secondly, they maintained that ethical responsibility is concerned with businesses fulfilling their obligations toward their shareholders, suppliers, distributors and other agents with whom they make their dealings. Singh et al. (2007) argued that ethical responsibility involves the respect for the human rights and norms that are defined in the law when carrying out business 
activities. They hinted that respecting ethical principles in business relationships has more priority over achieving superior economic performance. Their other domain, the social responsibility is concerned about laudable behaviours. The authors suggest that businesses could allocate part of their budget to the natural environment, philanthropy, or toward social works that favoured the most vulnerable in society. This perspective supports the development of financing social and/or cultural activities and is also concerned with improving societal wellbeing.

\section{Social Responsibility Policies}

The governments are usually considered as the main drivers of CSR policy. However, there are other actors within society, such as civil organizations and industry (Camilleri, 2015). It is within this context that a relationship framework has been suggested by Mendoza (1996) and Midttun (2005). It seems that at the time, there was a need for a deeper understanding of the governments' role and function in promoting CSR. Societal governance is intrinsically based on a set of increasingly complex and interdependent relationships (Albareda, Lozano and Ysa, 2007). There are different expectations and perceptions within each stakeholder relationship, which have to be addressed in order to develop an appropriate CSR policy, as featured in Figure 1 (Camilleri, 2015). Essentially, this relational approach is based on the idea that recent changes and patterns affecting the economic and political structure may transform the roles and capacities of various social agents (Albareda, Lozano, Tencati, Midttun and Perrini, 2008). The exchange relationships among different actors and drivers that are shaping CSR policy and communications. 
Figure 1. Actors and Exchange Arenas

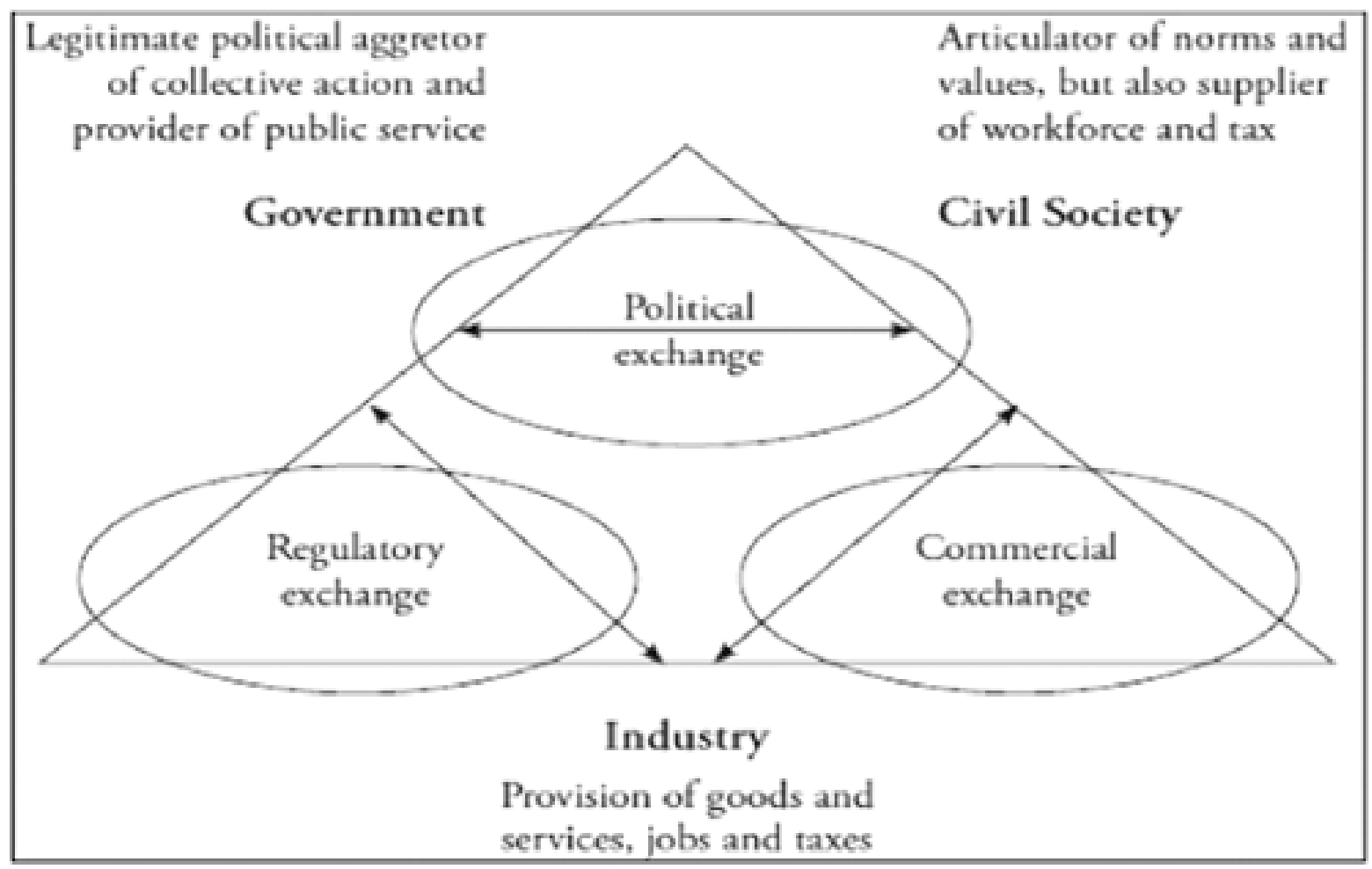

(Camilleri, 2015, Adapted from Albareda et al., 2007)

This exchange arena is exemplified in the U.S. government's comprehensive approach to providing support and guidance on areas of corporate conduct and sustainable behaviours. The U.S. secretary of state's agenda is to ensure effective coordination and partnerships with individual bureaus and offices in order to harness global economic tools that advance U.S. foreign policy goals on responsible initiatives. For example, the U.S. Bureau of Economic and Business Affairs (EB) leads a corporate social responsibility team. Its primary purpose is to promote responsible business practices and fostering sustainable development whilst building economic security. This team provides guidance to American companies and their stakeholders to engage in corporate citizenship. EB's CSR team supports major areas of responsible corporate conduct, including: 'good corporate citizenship', 'human rights', 'labour and supply chains', 'anticorruption', 'health and social welfare', 'contribution to the growth and development of the local economy', 'innovation, employment and industrial relations', 'environmental protection', 'natural resources governance' including the Kimberley Process, 'transparency', 'trade and supply chain management', 'intellectual property' and the 'women's 
economic empowerment' among other issues. Most of EB's corporate policies are drawn from the Organisation for Economic Co-operation and Development (OECD) 'Guidelines for Multinational Enterprises' and from U.S. national contact point for the guidelines (as explained hereunder).

\section{Good Corporate Citizenship and Human Rights}

In 1998, the Bureau of Democracy, Human Rights and Labour (DRL) set up a Human Rights and Democracy Fund (HRDF) to fulfil the bureau's mandate of monitoring and promoting human rights and democracy in the global context. The HRDF fund was designed to act as the department's "venture capital" fund for democracy and human rights issues, including; the promotion of democratic principles and personal liberties. Such programs enabled the U.S., "to minimize human rights abuses, to support democracy activists worldwide, to open political space in struggling or nascent democracies and authoritarian regimes, and to bring positive transnational change". DRL's important efforts have brought positive change as its funding of HRDF has grown from \$7.82 million in 1998 to over \$207 million in 2010 (HRDF, 2015).

In parallel, an 'Office to Monitor and Combat Trafficking in Persons (TIP) works with business leaders to prevent and stop human trafficking. TIP does this by advancing the Luxor Guidelines, which focus on corporate policy, strategic planning, public awareness, supply chain tracing, government advocacy and transparency to reduce forced labour in supply chains. In 2015, TIP Office awarded over $\$ 18$ million in grants and cooperative agreements to combat human trafficking. This office continues to fund an emergency global assistance project that provides services on a case-by-case basis for individuals that have been identified as trafficked persons (TIP, 2015).

Currently, many NGOs and international organisations are working in tandem as they support 27 projects that address prosecution, protection and prevention of sex and labour trafficking in different places around the globe (TIP, 2015). On the $28^{\text {th }}$ October, 2015, the Partnership for Freedom in collaboration with the Department of State and four other federal agencies launched "Rethink=Supply Chains: The Tech Challenge to Fight Labour Trafficking", an innovation challenge that calls for technological solutions that identify and address labour trafficking in global supply chains for goods and services. The Partnership for Freedom has awarded 
$\$ 500,000$ in prizes and services that are aimed to spur innovative solutions to end human trafficking, and to support victims of human trafficking in the United States.

\section{Labour and Supply Chains}

America made human trafficking illegal in 2000, after which it started to publish annual assessments of other countries' efforts to tackle it. But it has only slowly turned up the heat on offenders within its borders. Australia and the UK have recently passed light-touch laws requiring transparency in supply chains. This legislation required manufacturers and retailers that earn global revenues above the $\$ 100 \mathrm{~m}$ threshold to list their efforts on how they are eradicating modern slavery and human trafficking from their supply chains. For the time being, a firm can comply by simply reporting that it is doing nothing. But it seems that few corporations are willing to admit such a statement that will surely affect their CSR credentials. Hence, it seems that this issue is forcing its way on to managers' to-do lists. Moreover, the ILO has launched a fair-recruitment protocol which it hopes will be ratified by national governments. The ILO's intention is to cut out agents. In this light, TIP has partnered with Slavery Footprint to provide online tools to initiate marketplace action and ongoing dialogues between individual consumers and producers about modern slavery practices in supply chains (TIP, 2015). Similarly, DRL continues to promote labour rights throughout the supply chain as it enforces labour law and provides due diligence. DRL has also strengthened legal advocacy that expanded livelihood opportunities for many individuals, as it advanced multi-stakeholder approaches. EB, in cooperation with DRL and other stakeholders, has coordinated the U.S. Department of State's participation in the Kimberley Process to stem the flow of conflict diamonds and to address their traceability across supply chains.

\section{Anti-Corruption}

The corruption undermines sound public financial management and accountability at all institutional levels: It deters foreign investment in many countries, it stifles economic growth and sustainable development, it distorts prices, and undermines legal and judicial systems (INL, 2006). The high-level, large-scale corruption by public officials is also referred to as kleptocracy. It can have a devastating effect on democracy, the rule of law, and economic 
development. Those who contribute to such corruption by paying or promising to pay bribes or by giving other undue advantages to foreign public officials will undermine good governance and alter fair competition. The U.S. has long led by example in its enduring fight against corruption. Through its Foreign Corrupt Practices Act (FCPA) in 1977, the U.S. became the first country to criminally penalise its nationals and companies that bribe foreign public officials in commercial transactions. In fact, the United States denies safe haven to egregiously corrupt officials and other public figures as specified in the Presidential Proclamation 7750 (of January 2004). Moreover, the United Nations Convention Against Corruption (UNCAC) has also provided a framework for international cooperation against corruption, including preventative and enforcement measures. The U.S. government has participated in drafting U.N. legislative guide materials prior to its implementation and enforcement (INL, 2006). The USA is also member of the OECD's Anti-Bribery Convention where EB represents the U.S. Department of State within the OECD Working Group on Bribery in International Business Transactions.

\section{Health and Social Welfare}

In the United States, public education was not considered as a social welfare activity, probably because it is taken for granted, since its inception 125 years ago. On the other hand, public health and vocational rehabilitation are not included within the Social Security Act, but are present in separate Federal laws. However, medical care and cash benefits have always been provided under the workmen's compensation laws. These laws cover work-injuries and members of the armed forces and their dependents, and veterans who are entitled to medical care at public expense.

Interestingly, landmark reform on the Patient Protection and Affordable Care Act (PPACA), and the Health Care and Education Reconciliation Act (HCERA) of 2010 (H.R. 4872) was passed and enacted through two federal statutes. PPACA was signed in March 23, 2010. This act which is also known as 'Obamacare', provided the phased introduction over four years of a comprehensive system of mandated health insurance with reforms that were designed to eliminate "some of the worst practices of the insurance companies", including pre-existing condition screening and premium loadings, policy cancellations on technicalities when illness seems imminent, annual and lifetime coverage caps, among other issues. It also sets a minimum 
ratio of direct health care spending to premium income; and creates price competition that was bolstered by the creation of three standard insurance coverage levels to enable like-for-like comparisons by consumers; and a web-based health insurance exchange where consumers can compare prices and purchase plans (PPACA, 2010). This system preserves private insurance and private health care providers and provides more subsidies to enable the poor to buy insurance. Notwithstanding, the Health Care and Education Reconciliation Act of 2010 (H.R. 4872), which amended PPACA (that was passed a week earlier), was enacted by the 111th United States Congress and became law on March 30, 2010 (Reuters, 2010). This latter act (H.R. 3221) also incorporated the Student Aid and Fiscal Responsibility Act (SAFRA) expanded federal Pell Grants to a maximum of \$5,500 in 2010 and tied grant increases to annual increases in the Consumer Price Index, plus 1\%. Therefore, SAFRA ended the practice of federal subsidization of private loans. This has translated to cutting the federal deficit by $\$ 87$ billion over a period of 10 years.

\section{Policies for Environmental Sustainability}

\section{Energy and the Environment}

Historically, the United States prides itself of a long tradition of environmental leadership, that dates back to President Teddy Roosevelt. As a matter of fact, in the 1960s and 1970s the U.S. established a series of progressive laws and institutions. For example The National Environmental Policy Act (NEPA) of 1969 committed the United States to sustainability, declaring it a national policy "to create and maintain conditions under which humans and nature can exist in productive harmony that permit fulfilling the social, economic and other requirements of present and future generations" (NEPA, 1969).

The formulation of the Environmental Protection Agency's (EPA) policies and instruments have anticipated Brundtland's concept of "sustainable development" and his idea that generates clean prosperity today whilst preserving resources and ecological functions for use by future generations. Arguably, policies on social and environmental development are expected to reinforce responsible practices on resource management, energy efficiency and measures that mitigate climate change. In this regard, EPA has developed a variety of methods, tools and guidance programmes that are aimed at supporting the application of environmental sustainability. Moreover, the Bureau of Energy Resources (ENR) advances U.S. interests with 
regards to secure, reliable and ever-cleaner sources of energy. ENR promotes good governance and transparency in the energy-sector as it supports the Extractive Industries Transparency Initiative (EITI). Countries implementing the EITI disclose information on tax payments, licences, contracts, production and other key elements that revolve around resource extraction. This information is disclosed in an annual EITI Report. This transparent report allows citizens to see for themselves how their country manages its natural resources and it also specifies the revenue that they generate. The EITI Standard contains a set of requirements that countries, including the U.S., need to meet in order to qualify as an EITI Candidate or EITI Compliant country (EITI, 2015).

\section{Discussion and Conclusions}

Arguably, the social and environmental responsibility is the only way forward for all nations, particularly for big economies like China, the U.S., Russia and India. These countries are the largest producers of emissions and greenhouse gases in the world. This article shed light on the US governmental institutions and agencies' credentials on socially and environmentally responsible policies. It described in detail relevant instruments including relevant legislation and executive orders that were intended to unlock corporate citizenship among business and industry. At the same time, it reported how many commentators including academia are suggesting that the United States is lagging behind many other countries, in developing more sustainable economic processes and energy infrastructure. Environmental lobbyists argue that in the past three decades, average temperatures in the continental U.S. rose five times as much, than in a century-long period. A new report from the Worldwatch Institute, entitled; "Creating Sustainable Prosperity in the United States: The Need for Innovation and Leadership” called for a broad range of policy innovations in the areas of renewable and non-renewable resource use, waste and pollution, and population. This NGO purports that U.S. leaders have not implemented adequate and sufficient reforms on social and environmental responsibility. Arguably, at the moment many businesses are still characterised by their unsustainable practices such as linear flows of materials, heavy dependence on fossil fuels, disregard for renewable resources, and resource use. According to Columbia University's Environmental 
Sustainability Index (ESI), the US has merely scored 38 out of 100 in "global stewardship" and 27 out of 100 in "reducing stresses".

These results suggest the US's poor performance in mitigating air and water pollution and ecosystem stresses is the outcome of the country's minimal responsibility and sensitivity toward global environmental institutions (and international treaties). Notwithstanding, in a recent survey among seventeen countries by National Geographic, the American consumers ranked among the last in their green consumption habits (Greendex, 2012). Moreover, Chen and Bouvain (2009) reported that the percentage of U.S. companies that were members of the Global Compact was much lower than in the other countries. This finding could indicate that certain aspects of the Compact may not be acceptable to the U.S. corporations. Maybe, the relatively low environmental credentials among U.S. businesses and individual citizens transcends from the political arena. Although, the U.S. regularly attends to the annual conferences of the parties (COPs) that are organized by to the United Nations Framework Convention on Climate Change (UNFCCC), yet consecutive governments, since Clinton's administration did not transpose Kyoto's protocol. One of the strengths of the Kyoto treaty was the establishment of an international emissions trading system, where countries can earn credits toward their emission target; by investing in emission clean-ups outside their own country.

This review paper reported there are a number of corporate citizenship and social responsibility policies that are still evolving in the US context. Arguably, national institutional structures are creating both challenging opportunities and threats for businesses. US corporations are already operating in various contexts where they could be mandated by law to abide by national legislation and regulation. Notwithstanding, there are different CSR communications and stakeholders' evaluations of given firms across countries. Despite the growing commitment to corporate citizenship, past research did not sufficiently link this notion with CSR policy. This contribution has reported how different U.S. institutions, including bureaus, agencies and other stakeholders are pushing forward the social responsibility, environmental sustainability as well as the responsible corporate governance agenda. The US CSR policies and instruments are generally (i) based on sound theoretical arguments (ii) tackle the economic, legal, ethical, and discretionary dimensions. However, these regulatory tools could contain disclosure guidelines and reporting mechanisms for the monitoring and controlling of corporate responsible behaviours in the U.S. 
The U.S. Government to trigger companies to invest in more efficient technologies by subsidising cleaner production and circular economies. Alternatively, businesses can be penalised when they do not conform to regulatory requirements on responsible behaviours (e.g. reducing environmental impact) (Moratis and Slaa, 2016). For instance, with carbon pricing, governments cannot interfere with management decisions. The businesses themselves ought to decide on effective ways on how they cut their emissions. Carbon markets are there and are expanding (e.g. The EU's Emissions Trading Scheme - ETS). There are many lessons to be learned from the countries' that have resorted to ETS to curb their pollution on the environment. Perhaps, one of the challenges for policymakers is the monitoring and controlling of carbon markets. Indeed, it is in the businesses' interest to anticipate the reinforcement of extant regulatory instruments or any mandatory compliance procedures to new legislation. The firms' proactive corporate citizenship behaviours will inevitably lead them to a sustainable competitive advantage, particularly at times when the market is not working well.

\section{Implications and Recommendations}

Although there have been many contributions on corporate citizenship practices (Pinkston and Carroll, 1994; Maignan et al. 1999; Matten and Crane, 2005; Fifka, 2013), there is still considerable potential for research that focuses on regulatory policy, in this regard. Future research could measure the comparability of policy frameworks for corporate citizenship in the US with other states. Notwithstanding, CSR policies, procedures, and activities necessitate considerable discretionary investments, in terms of time and resources by policy makers, civil authorities, businesses and non-governmental organisations. The underlying question is to establish whether both companies and non-for profit organisations perceive a business or a political case for corporate citizenship, as there potential to create value for themselves and for society as they pursue the sustainable path.

The increased quality of life has brought unsustainable consumption behaviors among customers. Notwithstanding, increased productivity levels are rapidly depleting the world's natural resources. This research has indicated that on paper there are several policies frameworks and initiatives that are pushing forward the corporate citizenship agenda in the U.S. However, the proof is in the pudding. Debatably, the U.S. government and its agencies 
should ensure that the true ecological cost of environmental degradation and climate change is felt in the market. In this light, there is scope in promoting circular economies that are characterised by resource efficiencies through recycling, reducing and reusing. Moreover, organisations should be urged to find alternative ways for sustainable energy generation, energy and water conservation, environmental protection and greener transportation systems.

Corporate citizenship policies should be promoting socially-responsible investing (SRI), responsible supply chain management and the responsible procurement of sustainable products. Fiscal policies and tools could encourage consumers to purchase sustainable, ecolabelled products, standardized items and 'fair-trade' goods.

\section{References}

Albareda L, Lozano JM, Ysa T. 2007. Public policies on corporate social responsibility: The role of governments in Europe. Journal of Business Ethics. 74(4):391-407.

Albareda L, Lozano JM, Tencati A, Midttun A, Perrini F. 2008. The changing role of governments in corporate social responsibility: drivers and responses. Business ethics: a European review. 17 (4): 347-63.

Albinger HS, Freeman SJ 2000. Corporate social performance and attractiveness as an employer to different job seeking populations. Journal of Business Ethics 28 (3): 243-253.

Aupperle KE, Carroll AB, Hatfield JD 1985. An empirical examination of the relationship between corporate social responsibility and profitability. Academy of Management Journal 28 (2): 446-463.

Basu K, Palazzo G 2008. Corporate social responsibility: A process model of sensemaking. Academy of Management Review 33 (1): 122-136.

Brammer S, Pavelin S. 2005. Corporate community contributions in the United Kingdom and the United States. Journal of Business Ethics 56 (1): 15-26.

Burke L, Logsdon JM. 1996. How corporate social responsibility pays off. Long range planning 29 (4):495-502.

Camilleri MA, 2015. Valuing Stakeholder Engagement and Sustainability Reporting. Corporate Reputation Review 18 (3): 210-222.

Carroll AB, 1979. A three-dimensional conceptual model of corporate performance. Academy of Management Review 4 (4): 497-505. 
Carroll AB, 1991. The pyramid of corporate social responsibility: Toward the moral management of organizational stakeholders, Business Horizons 34 (4): 39-48.

Carroll AB, Shabana, KM, 2010. The business case for corporate social responsibility: a review of concepts, research and practice. International Journal of Management Reviews 12 (1): 85-105.

Chen S, Bouvain P, 2009. Is corporate responsibility converging? A comparison of corporate responsibility reporting in the USA, UK, Australia, and Germany. Journal of Business Ethics 87 (1), 299-317.

Clarkson ME, 1995. A stakeholder framework for analyzing and evaluating corporate social performance. Academy of management review, 20 (1): 92-117.

Doh JP, Guay TR, 2006. Corporate social responsibility, public policy, and NGO activism in Europe and the united states: An Institutional-Stakeholder perspective. Journal of Management Studies, 43 (1): 47-73.

DRL, 2015. DRL Programs. Human Rights and Democracy Fund. Bureau of Democracy, Human Rights and Labour. http://www.state.gov/j/drl/p/ [20 November 2015].

EEA, 1999. Environmental indicators: Typology and overview. http://www.eea.europa.eu/publications/TEC25 [20 November 2015].

EITI, 2015. Extractive Industries Transparencies Initiative. https://eiti.org/eiti [20 November 2015].

EPA, n.d. Overview by Section of the Clean Air Act. U.S. Environmental Protection Agency. http://www3.epa.gov/airtoxics/overview.html [8 November 2015].

EPA, 2015. Laws and Regulations. U.S. Environmental Protection Agency. http://www2.epa.gov/laws-regulations [17 November 2015].

Fifka MS. 2013. Corporate citizenship in Germany and the United States-differing perceptions and practices in transatlantic comparison. Business Ethics: A European Review 22 (4): 341-356.

Fombrun CJ. 1998. Indices of corporate reputation: An analysis of media rankings and social monitors' ratings. Corporate reputation review 1 (4): 327-340.

Fryxell GE, Wang J, 1994. The fortune corporate 'reputation' index: Reputation for what?. Journal of management, 20 (1): 1-14.

Greendex, 2012. Consumer Choice and the Environment. A Worldwide Tracking Survey http://images.nationalgeographic.com/wpf/mediacontent/file/NGS_2012_Final_Global_report_Jul10-cb1341951434.pdf [25 November 2015]. 
Griffin J.J, Mahon JF, 1997. The corporate social performance and corporate financial performance debate twenty-five years of incomparable research. Business \& Society, 36 (1): $5-31$.

HRDF, 2015. DRL Programs: Human Rights and Democracy Fund http://www.state.gov/j/drl/p/ [17th November 2015].

Hunt SD, Wood VR, Chonko LB, 1989. Corporate ethical values and organizational commitment in marketing. The Journal of Marketing: 79-90.

IFAP, 2003. Student Eligibility In Pell Grants, Chapter 1, 3-10.

https://ifap.ed.gov/sfahandbooks/attachments/0304Vol3Ch1.pdf [10 November 2015].

IIP, 2015. Bureau of International Information Programs http://www.state.gov/r/iip/ [10 November 2015].

INL, 2006. U.S. Strategy to Internationalize Efforts Against Kleptocracy: Combating HighLevel Public Corruption, Denying Safe Haven, and Recovering Assets http://20012009.state.gov/p/inl/rls/fs/70365.htm [20 November 2015].

Kotler P, Lee N, 2005. Corporate social responsibility. Doing the Most Good for Your Company and Your Cause, New Jersey.

Matten D, Crane A, 2005. Corporate citizenship: Toward an extended theoretical conceptualization. Academy of Management review 30 (1): 166-179.

Maignan I, Ferrell OC, Hult, GTM, 1999. Corporate citizenship: cultural antecedents and business benefits. Journal of the Academy of Marketing Science 27(4): 455-469.

Mendoza, X. 1996. Las transformaciones del sector público en las sociedades avanzadas. Del estado del bienestar al estado relacional. Papers de Formació 23 Diputació de Barcelona.

Midttun, A. 2005. Policy making and the role of government. Realigning business, government and civil society. Emerging embedded relational governance beyond the (neo)liberal and welfare state models. Corporate Governance: International Journal of Business in Society, 5(3): 159-174.

Moratis L, Slaa AM. 2016. Sticks in a Bundle Are Unbreakable: The Creation of a Kenyan CSR Knowledge Centre and Business Network. In Key Initiatives in Corporate Social Responsibility (pp. 399-417). Springer International Publishing.

NEPA, 1969. Summary of the National Environmental Policy Act. Law and Regulations, US Enivironmental Protection Agency. http://www2.epa.gov/laws-regulations/summarynational-environmental-policy-act [16 November 2015]. 
Pinkston TS, Carroll AB, 1994. Corporate citizenship perspectives and foreign direct investment in the US. Journal of Business Ethics 13 (3): 157-169.

PPACA, 2010. The Patient Protection and Affordable Care Act: An Overview of Its Potential Impact on State Health Programs.

http://www.lao.ca.gov/reports/2010/hlth/fed_healthcare/fed_healthcare_051310.aspx

accessed on the 2nd October 2015.

Porter ME, Kramer MR, 2002. The competitive advantage of corporate philanthropy.

Harvard business review 80 (12): 56-68.

Porter ME, Kramer MR, 2011. Creating shared value: How to reinvent capitalism - and unleash a wave of innovation and growth'. Harvard Business Review (January/February): $62-77$.

Rasche A, De Bakker FG, Moon J. 2013. Complete and partial organizing for corporate social responsibility. Journal of Business Ethics. 115(4):651-63.

Reuters, 2010. Factbox-U.S. healthcare bill would provide immediate benefits. http://www.reuters.com/article/usa-healthcare-rolloutidUSN1914020220100322\#vlGrBoWEAWZE7UER.97 [31 October 2015].

Schwartz MS, Carroll, AB, 2003. Corporate social responsibility: A three-domain approach. Business Ethics Quarterly 13 (4): 503-530.

Singhapakdi A, Kraft KL, Vitell SJ, Rallapalli KC, 1995. The perceived importance of ethics and social responsibility on organizational effectiveness: A survey of marketers. Journal of the Academy of Marketing Science 23 (1): 49-56.

Stanwick PA, Stanwick SD, 1998. The relationship between corporate social performance, and organizational size, financial performance, and environmental performance: An empirical examination. Journal of Business Ethics 17 (2): 195-204.

Strand R, Freeman RE, 2013. Scandinavian cooperative advantage: The theory and practice of stakeholder engagement in Scandinavia. Journal of Business Ethics 127 (1): 65-85.

Singh J, Del Bosque IR, 2008. Understanding corporate social responsibility and product perceptions in consumer markets: A cross-cultural evaluation. Journal of Business Ethics $\mathbf{8 0}$ (3): 597-611.

TIP, 2015. Office to Monitor and Combat Trafficking in Persons. http://www.state.gov/j/tip/ [14 November 2015].

Varadarajan PR, Menon A, 1988. Cause-related marketing: A coalignment of marketing strategy and corporate philanthropy. The Journal of Marketing, 58-74. 
U.S. Geological Survey, 2010. Mineral Commodity Summaries. U.S. Department Of the Interior. http://minerals.usgs.gov/minerals/pubs/mcs/2010/mcs2010.pdf [10 November 2015].

Van Riel CB, Fombrun CJ, 2007. Essentials of corporate communication: Implementing practices for effective reputation management. Routledge.

Waddock SA, Graves SB, 1997. The corporate social performance-financial performance link. Strategic management journal 18 (4): 303-319.

Wartick SL, Cochran PL, 1985. The evolution of the corporate social performance model. Academy of management review 10 (4): 758-769.

Webb DJ, Mohr, LA, Harris KE, 2008. A re-examination of socially responsible consumption and its measurement Journal of Business Research 61 (2): 91-98.

Wheeler D, Colbert B, Freeman, RE. 2003. Focusing on Value: Reconciling Corporate Social Responsibility, Stakeholder Theory and Sustainability in a Network World. Journal of General Management 28 (3): 1-28.

Wood DJ, 1991. Corporate social performance revisited. Academy of management review 16 (4): 691-718.

WorldWatch, 2015. U.S. Must Commit to Sustainability to Overcome Mounting Economic and Ecological Strains http://www.worldwatch.org/us-must-commit-sustainabilityovercome-mounting-economic-and-ecological-strains [25 November 2015]. 